\title{
Establishment of Quality Standards of Abrus precatorius Linn. Seed
}

\author{
SHAZIA TABASUM ${ }^{*}$, SWATI KHARE ${ }^{1}$ AND KIRTI JAIN \\ Department of Botany, Government Science And Commerce College, Bhopal-462 008, ${ }^{1}$ Department of Botany, Govt. Girls \\ MLB College, Bhopal-462 001, India
}

Tabasum et al.: Quality parameters of Abrus precatorius Linn. Seeds

\begin{abstract}
Standardization of herbal formulations is an important aspect while considering the quality of the herbal drug, consistency in active principle content and therapeutic efficacy. The seeds of Abrus precatorius Linnaeus, a well-established medicinal plant belonging to the family Fabaceae is commonly known as Gunja or Rati. In view of its medicinal importance the present study was conducted to standardize the crude drug according to the standard laboratory methods and to define pharmacopoeial standards for the seeds of this species. Qualitative phytochemical analysis and physiochemical studies of the powdered drug using various methods including organoleptic analysis, ash value, extractive value, thin-layer chromatography, loss on drying, and fluorescence analysis were performed to establish quality standards of the herb, which would help in identification as well as develop quality assurance parameters for herbal formulations containing this herbal product as an active component.
\end{abstract}

Key words: Abrus precatorius, standardization, quality, phytochemical analysis

Medicinal plants have been known for millennia and are highly appreciated all over the world as a rich source of therapeutic agents for curing various diseases and disorders ${ }^{[1]}$. Today, people are much aware of medicinal plant resources and are showing great interest towards the herbal drugs and products by making their use in health maintenance and prevention of various diseases and ailments ${ }^{[2,3]}$. This rising interest towards the herbal medicines is because of the traditional belief that these are cheap, safe and natural without harmful effects ${ }^{[4]}$. Medicinal plants are also major raw materials for pharmaceutical industry and thus have gained importance in global drug market. However, the unavailability of documentation and rigorous quality control acts as a key hindrance in the approval of herbal products as alternative medicine in the developed countries. Thus, it is very important to make significant efforts towards standardization of the plant materials along with documentation for those to be used as medicines ${ }^{[3]}$.

Standardization of herbal medicines is the process to lay down a set of technical standard parameters for the assurance of quality, safety, efficacy and reproducibility for each herb. Such constant parameters are developed by observation and experimentation to confirm a set of

*Address for correspondence E-mail: shaziatabasum49@gmail.com

May-June 2018 characteristics exhibited by a particular medicinal herb or its products. Hence the process of standardization is a basic tool in the quality assurance of herbal medicine ${ }^{[5]}$ that can be attained by stepwise phytochemical and pharmacognostic investigations. These studies help in correct identification, classification and standardization of the plant material. Proper identification and quality assurance of the starting plant materials is a fundamental requirement to establish the reproducible quality of herbal medicinal products that will contribute to their safety and efficacy ${ }^{[6,7]}$.

Abrus precatorius L. commonly known as Rosary pea, Indian liquorice, Jequirity and Crab's eye is an important medicinal plant belonging to the family Fabaceae. It is known as Ratti in Hindi and Gunja in Sanskrit. Plant is native to India, but now found almost in all tropical and sub-tropical areas throughout the world $^{[8]}$. A. precatorius is a twinning climber with herbaceous branches and pinnate leaves. The flowers

This is an open access article distributed under the terms of the Creative Commons Attribution-NonCommercial-ShareAlike 3.0 License, which allows others to remix, tweak, and build upon the work non-commercially, as long as the author is credited and the new creations are licensed under the identical terms

Accepted 30 March 2018

Revised 14 August 2017

Received 11 June 2016

Indian J Pharm Sci 2018;80(3):541-546 
are purple pink or reddish in colour and are borne in clusters. Fruits are pods bearing characteristic red seeds with a black spot round the hilum ${ }^{[9]}$. The seeds have remarkably uniform weight of $1 / 10^{\text {th }}$ of a gram, therefore were used by goldsmiths as standard weight for weighing gold and silver in previous time ${ }^{[10]}$. It was first recognized and mentioned as a homoeopathic medicine by William Boericke in his Homoeopathic Materia Medica under the heading of Jequirity ${ }^{[11]}$. The plant is used in some traditional medicine to treat scratches, sores and wounds caused by dogs, cats and mice; and are also used with other ingredients to treat leucoderma, tetanus and rabies ${ }^{[10]}$. Seeds are useful in diarrhoea, dysentery and have antidiabetic ${ }^{[12]}$, antitumor and proapoptotic ${ }^{[13]}$, antibacterial, anthelmintic ${ }^{[14,15]}$ and protective effect against alcohol-induced renal damage ${ }^{[16]}$. Seeds are considered to be purgative, emetic, tonic, antiphlogistic, aphrodisiac, antiophthalmic ${ }^{[17]}$ and abortifacient ${ }^{[18]}$. Seeds are also poisonous but after mitigation are said to have very powerful aphrodisiac property. These are also used in veterinary medicine for the treatment of fracture ${ }^{[19-22]}$. It is said that cooking destroys the poison of seeds ${ }^{[23,24]}$. A protein called abrin is responsible for their toxic properties ${ }^{[8]}$. In view of its medicinal importance, present study was performed to standardize $A$. precatorius seeds on the basis of phytochemical and physicochemical parameters.

\section{MATERIALS AND METHODS}

\section{Seed collection and authentication:}

Firstly the mature seeds of $A$. precatorius (fig. 1A) were purchased from the local market of Bhopal, Madya Pradesh, India and were identified and authenticated in the Department of Botany, Safia Science College, Bhopal, Madya Pradesh, India. A sample voucher specimen No. 520/Bot/Saifia/2015 was deposited there for further reference.

\section{Extraction $^{[25]}$ :}

The seeds were washed with distilled water to remove residual material and were shade-dried. After drying, seeds were crushed into a coarse powder (fig. 1B) using an electrical grinder. A part of this dried coarse powder of $A$. precatorius was filled and stored in air tight containers for physiochemical and other studies in future. The remaining powder was extracted with petroleum ether and the marc remaining was air-dried and extracted successively by $70 \%$ methanol through maceration process. Filtrates obtained from both the solvents were evaporated in a rotary evaporator under
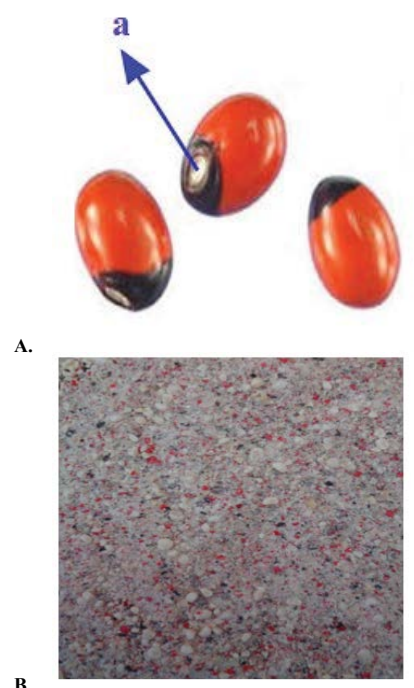

Fig. 1: Abrus precatorius L. mature seeds (A) and powder (B) a. Hilum

reduced pressure, vacuum-dried and were packed in air tight containers, labelled and stored in a refrigerator $\left(2-4^{\circ}\right)$ until needed for the experimental purpose. Percent yield of the extracts were calculated with reference to air-dried power as: percent yield $=$ weight of extract/weight of plant material $\times 100$.

\section{Standardization parameters:}

Organoleptic evaluation ${ }^{[26]}$ is a method of qualitative evaluation based on study of morphological and sensory profiles of crude drugs. Organoleptic characteristics including colour, odour, taste and texture of seed powder. Petroleum ether extract and methanol extracts were evaluated using reported methods. Loss on drying ${ }^{[27]}$ gives an estimate of the moisture present in a crude drug. The moisture content of the powdered drug was determined by the loss on drying method as per standard procedure.

Determination of ash value ${ }^{[25,27]}$ allows for detecting low-grade drugs, exhausted drugs and sandy or earthy matter. The ash value was determined by four different methods, which measure total ash, acid-insoluble ash, water-soluble ash and sulphated ash, using standard methods. Extractive values ${ }^{[25,27]}$ of the crude drug in different solvents such as distilled water, chloroform, ethanol, ethyl acetate, methanol and petroleum ether were determined as per standard methods.

The fluorescence characteristics ${ }^{[3]}$ of the fine seed powder as such and with different reagents was examined in both visible and UV light (254 and 366 $\mathrm{nm}$ ) using reported methods. Changes in colour of the sample when treated with different reagents were recorded under visible and UV light (254 and $366 \mathrm{~nm}$ ). 
Qualitative phytochemical analysis ${ }^{[25]}$ is based on the property of selective reactivity of phytochemicals present in extracts formed the basis of chemical tests for identification of various compounds. Phytochemical screening was performed for analysing secondary metabolites, which were believed to be responsible for useful pharmacological effects with therapeutic application. The preliminary phytochemical screening for secondary metabolites was carried out on petroleum ether and methanol $(70 \%)$ seed extracts of $A$. precatorius using standard procedures. The phytochemicals tested for were alkaloids, flavonoids, carbohydrates, tannins, steroids, proteins, triterpenes, glycosides, saponins, and fat and oils. Presence and absence of phytochemical constituents were noted.

Chromatographic analysis ${ }^{[26-28]}$ was carried out using thin-layer chromatography (TLC), which is one of the most useful techniques employed for separation, identification and estimation of single or mixture of components present in different plant extracts. In the present study, TLC was carried out for $70 \%$ methanol and petroleum ether extracts of $A$. precatorius seeds using various solvent systems as per the standard methods to find out the probable number of compounds present in these extracts. The extracts were spotted on activated silica gel plates. After development TLC plates were observed under visible and UV light (short- $254 \mathrm{~nm}$ and long- $365 \mathrm{~nm}$ ). The retention factor (Rf) for each spot observed was calculated using the formula as: $\mathrm{Rf}=$ spot distance from origin/solvent front distance from origin.

\section{RESULTS AND DISCUSSION}

It is very important and in fact an essential prerequisite to establish the standard specifications of medicinal plants used in the preparation of various drugs. The study of natural drugs mostly of plant origin is known as pharmacognosy. It mainly deals with identification, authentication and quality control of herbal medicines. Most of the research in pharmacognosy has been done to identify controversial species of plants, authentication of commonly used traditional medicinal plants through morphological, phytochemical and physicochemical analysis ${ }^{[29]}$. Hence, in recent years there has been increased emphasis on standardization of medicinal plants, of which evaluation of plant drugs using pharmacognostic studies appears to be more reliable, accurate and economical. Pharmacognostic parameters and standards must be established for all the crude drugs prior to their incorporation in herbal pharmacopoeia. The present study deals with the physicochemical and phytochemical evaluation of the seeds of $A$. precatorius, a well-known medicinally important plant.

Percent yield of the extracts in different solvents indicate the quantity and nature of various phytocomponents present in the crude drug. The percent yields of petroleum ether and $70 \%$ methanol extracts obtained by successive maceration method were 1.146 and $3.292 \% \mathrm{w} / \mathrm{w}$, respectively.

Organoleptic evaluation is the first step of establishing the identity and purity of the medicinal plant materials before further tests are performed. Organoleptic characters are very simple and quicker means to establish the quality and purity of a particular crude drug. Organoleptic evaluation indicated the brown colour, characteristic odour, bitter taste and sticky texture of the $70 \%$ methanol extract; and yellowish colour, pungent odour and oily texture of the petroleum ether extract. The value of loss on drying, expressed as a percent of air-dried material was $8.2 \% \mathrm{w} / \mathrm{w}$.

The ash value is particularly helpful in determination of purity and quality of drugs. A high ash value is indicative of adulteration, contamination, substitution or carelessness in preparing the crude drug for marketing. Low ash values indicate the purity of plant drugs. The values are expressed as percent of air-dried material. The values of total ash, acid-insoluble ash, water-soluble ash and sulphated ash were found to be $2.091,0.102,0.067$ and $1.019 \% \mathrm{w} / \mathrm{w}$, respectively.

Extractive values are valuable to evaluate the chemical constituents present in the crude drug and assist in estimation of specific components soluble in particular solvent. These are mainly helpful for the determination of exhausted and adulterated drugs. The extractive values of powdered drug in distilled water, methanol, ethanol, petroleum ether, chloroform and ethyl acetate extracts were 51.78, 9.10, 4.94, 3.20, 2.09 and $1.96 \% \mathrm{w} / \mathrm{w}$, respectively. The extractive value of powdered sample was thus found maximum in distilled water and least in ethyl acetate, which implied that most of the phytoconstituents of the seed were soluble in water. The values are expressed as percent of airdried material.

Fluorescence study is an essential parameter for first line standardization of crude drug. Light rich in short wavelengths is very active in producing fluorescence and for this reason ultraviolet light produces fluorescence in many substances, which do not 
visibly fluoresce in day light. The fluorescence colour is specific for every compound. The fluorescence analysis of seed powder displayed their characteristic fluorescent colour in different chemicals used. The results of fluorescence analysis were shown in Table 1.

Qualitative phytochemical screening gave valuable information about the various phytoconstituents present in the extracts, which could facilitate future investigators to select of a particular extract for further analysis of isolating the active principle. From preliminary phytochemical studies, $70 \%$ methanol extract was found to be rich in phytoconstituents than the petroleum ether extract. This investigation confirmed the presence of carbohydrates, proteins, amino acids, glycosides, saponins, alkaloids, terpenoids, steroids, flavonoids, tannins and phenolic compounds in $70 \%$ methanol extract; and carbohydrates, terpenoids, steroids, tannins and fats and oils in the petroleum ether extract. Presence of different phytochemicals in both the extracts revealed their therapeutic potential and offer specific distinctiveness and properties to the plant. The results of this investigation are compiled in Table 2.

TABLE 1: FLUORESCENCE ANALYSIS OF POWDERED ABRUS PRECATORIUS L. SEEDS

\begin{tabular}{lccc}
\hline Powdered crude drug+reagent & Visible Light & UV (short) 254 nm & UV (long) 366 nm \\
\hline Powder drug as such & Creamish-yellow & Fluorescent green & Light brown \\
Drug+methanol & Creamish-yellow & Fluorescent green & Brownish-green \\
Drug+ethanol & Yellowish-cream & Fluorescent green & Brownish-green \\
Drug+ethyl acetate & Yellowish-cream & Fluorescent green & Brownish-green \\
Drug+chloroform & Creamish-yellow & Fluorescent green & Brownish-green \\
Drug+concentrated $\mathrm{H}_{2} \mathrm{SO}_{4}$ & Brownish-red & Dark brown & Dark green \\
Drug+dilute $\mathrm{H}_{2} \mathrm{SO}_{4}$ & Reddish-grey & Greyish-yellow & Dark brown \\
Drug+concentrated $\mathrm{HCl}$ & Reddish-brown & Brownish-green & Dark brown \\
Drug+dilute $\mathrm{HCl}$ & Greyish-red & Fluorescent green & Brownish-black \\
Drug+n-hexane & Creamish-yellow & Fluorescent green & Greyish-brown \\
Drug+10\% $\mathrm{NaOH}$ & Brown yellowish & Brown greenish & Black \\
Drug+5 \% FeCl ${ }_{3}$ & Brown yellowish & Brown greenish & Black \\
Drug+distilled water & Creamish-yellow & Greyish-green & Brownish-green \\
Drug+ammonia solution & Creamish-yellow & Brownish-green & Dark green \\
Drug+concentrated acetic acid & Creamish-grey & Greyish-yellow & Greyish-brown \\
Drug+dilute acetic acid & Creamish-red & Brownish-green & Black \\
Drug+50 $\% \mathrm{KOH}$ solution & Brownish-yellow & Fluorescent green & Brownish-black \\
Drug+acetone & Creamish-yellow & Creamish-green & Greenish-brown \\
\hline
\end{tabular}

TABLE 2: PRELIMINARY PHYTOCHEMICAL ANALYSIS FOR CRUDE EXTRACTS OF EXTRACTS OF ABRUS PRECATORIUS L. SEEDS

\begin{tabular}{|c|c|c|c|}
\hline \multirow{2}{*}{ Phytochemicals } & \multirow{2}{*}{ Tests } & \multicolumn{2}{|c|}{ Observations } \\
\hline & & Methanol (70 \%) extract & Petroleum ether extract \\
\hline \multirow{2}{*}{ Carbohydrates } & Molisch's test & + & - \\
\hline & Benedict's test & + & + \\
\hline \multirow{2}{*}{ Proteins } & Biuret's test & + & - \\
\hline & Million's test & + & - \\
\hline Amino acids & Ninhydrin test & + & - \\
\hline Glycosides & Keller-Killiani test & + & - \\
\hline \multirow[t]{2}{*}{ Saponins } & Froth test & + & - \\
\hline & Mayer's test & + & - \\
\hline \multirow{3}{*}{ Alkaloids } & Wagner's test & + & - \\
\hline & Dragendorff's test & + & - \\
\hline & Hager's test & - & - \\
\hline \multirow{3}{*}{ Terpenoids and steroids } & Salkowski's test & + & + \\
\hline & Liebermann-Burchard's test & + & + \\
\hline & Lead acetate test & + & - \\
\hline \multirow[t]{2}{*}{ Flavonoids } & Alkaline reagent test & + & - \\
\hline & Shinoda test & + & - \\
\hline \multirow{2}{*}{ Tannins and Phenolics } & Ferric chloride test & + & + \\
\hline & Lead acetate test & + & - \\
\hline
\end{tabular}


TLC is particularly important for the preliminary separation and determination of plant constituents. It is a competent tool to standardize plant preparations. It is relatively simple, handy, easy, convenient, efficient and inexpensive technique for quick evaluation of the quality of herbal preparations. From qualitative chromatographic analysis of the petroleum ether and $70 \%$ methanol extracts, a number of spots were observed in different solvent systems used. It was found that the petroleum ether extract showed maximum separated components under longer wavelength UV light in a solvent system of chloroform:methanol $(15: 1)$. On the other hand, in case of the methanol extract, highest density of components were separated under visible light in solvent system composed of ethyl acetate:formic acid:water (8:1:1). The $\mathrm{Rf}$ values of the spots detected on TLC analysis of petroleum ether and methanol extracts developed in different solvent systems are presented in Table 3 and Table 4 . The TLC profile of the seed extracts of the A. precatorius furnished a preliminary view of the phytochemicals present in them.

In order to ensure the quality of herbal products, appropriate quality and purity of starting material is very important. Standardization is an essential measure for establishing quality, purity and sample identification. It will act as a tool to detect adulterants and substituents and will help in maintaining the quality, reproducibility and efficacy of natural drugs. Information obtained from these studies can be used as reference information for correct identification of particular plant and in distinguishing it from its

\section{TABLE 3: TLC ANALYSES OF METHANOL (70 \%) EXTRACT OF ABRUS PRECATORIUS SEEDS}

\begin{tabular}{|c|c|c|c|c|}
\hline Solvent system & Ratio & Condition & No. of spots & Rf value \\
\hline \multirow{4}{*}{ n-butanol:glacial acetic acid:water } & & UV long & 1 & 0.683 \\
\hline & $4: 1: 5$ & UV short & 2 & $0.7,0.85$ \\
\hline & & Visible & 2 & $0.916,0.716$ \\
\hline & & UV long & 2 & $0.242,0.314$ \\
\hline \multirow[t]{3}{*}{ Ethyl acetate:formic acid:water } & $8: 1: 1$ & UV short & 1 & 0.857 \\
\hline & & Visible & 3 & $0.408,0.281,0.225$ \\
\hline & & UV long & & \\
\hline \multirow[t]{3}{*}{ Chloroform:methanol } & $15: 1$ & UV short & $\overline{1}$ & $0 . \overline{1} 40$ \\
\hline & & Visible & 1 & 0.140 \\
\hline & & UV long & 1 & 0.231 \\
\hline \multirow[t]{3}{*}{ Ethyl acetate:formic acid:glacial acetic acid:water } & $100: 11: 11: 26$ & UV short & 1 & 0.246 \\
\hline & & Visible & 1 & 0.144 \\
\hline & & UV long & 2 & $0.213,0.053$ \\
\hline \multirow[t]{3}{*}{ Toulene:ethyl acetate:acetic acid } & $31: 14: 5$ & UV short & 1 & 0.213 \\
\hline & & Visible & 1 & 0.213 \\
\hline & & UV long & 1 & 0.708 \\
\hline \multirow[t]{2}{*}{ Ethyl acetate:formic acid:glacial acetic acid } & $36: 12: 5$ & UV short & 2 & $0.680,0.25$ \\
\hline & & Visible & 2 & $0.972,0.666$ \\
\hline
\end{tabular}

TABLE 4: TLC ANALYSES OF PETROLEUM ETHER EXTRACT OF ABRUS PRECATORIUS SEEDS

\begin{tabular}{lcccc}
\hline Solvent system & Ratio & Condition & No. of spots & Rf value \\
\hline n-butanol:glacial acetic acid:water & & UV long & 1 & 0.885 \\
& $4: 1: 5$ & UV short & 1 & 0.3 \\
& & Visible & - & - \\
& & UV long & 1 & 1.00 \\
Ethyl acetate:formic acid:water & $8: 1: 1$ & UV short & 1 & 0.972 \\
& & Visible & 1 & 1.00 \\
& & UV long & 3 & $0.94,0.838,0.750$ \\
Chloroform:methanol & $15: 1$ & UV short & 1 & 0.941 \\
& & Visible & - & - \\
Ethyl acetate:formic acid:glacial acetic acid:water & \multirow{2}{*}{$100: 11: 11: 26$} & UV long & 1 & 0.955 \\
& & UV short & 1 & 0.955 \\
& & Visible & 1 & 0.955 \\
Toulene:ethyl acetate:acetic acid & & UV long & 2 & $0.957,0.628$ \\
& $31: 14: 5$ & UV short & 1 & 0.957 \\
Ethyl acetate:formic acid:glacial acetic acid & & Visible & - & - \\
& & UV long & 1 & 0.953 \\
& $36: 12: 5$ & UV short & 1 & 0.953 \\
& & Visible & 1 & 0.953 \\
\hline
\end{tabular}


closely related species. Such studies are also helpful in authentication of the plant material, standardization and establishing the plant as a herbal remedy and also will be useful in making a monograph of the plant for the pharmacopoeia. By following these simple but reliable standards, a person could be very sure of using the crude drug as a home remedy. Physicochemical and phytochemical analysis of seeds confirms the quality and purity of plant and its identification. The study thus tends to scientifically authenticate the use of this plant in traditional medicine.

\section{Acknowledgements:}

The author is grateful to Department of Botany, Govt. Science and Commerce College Benazeer and Pinnacle Biomedical Research Institute (PBRI) Bhopal, Madhya Pradesh, India for providing laboratory facilities to carry out this work. The authors thank Dr. Zia-ulHassan, Head of the Department of Botany, Safia Science College Bhopal, Madya Pradesh for identifying and authenticating the plant material.

\section{Conflict of interest:}

The authors declare no conflict of interest.

\section{Financial support and sponsorship:}

Nil.

\section{REFERENCES}

1. Agarwal AK, Goyal P, Lakshminarasimhaiah, Goyal P, Singh GK. Pharmacognostical studies on a tropical plant, Syzygium cumini Linn. from Jodhpur district, Rajasthan, North West India. World J Pharm Pharm Sci 2015;4:1023-30.

2. Kadam, PV, Deoda RS, Shivatare RS, Yadav KN, Patil MJ. Pharmacognostic, phytochemical and physiochemical studies of Mimusops elengi Linn. stem bark (Sapotaceae). Der Pharma Lett 2012;4:607-613.

3. Uthayakumari F, Sumathy M. Pharmacognostical studies on the endemic medicinal plant- Jatropha maheswarii Subr. and Nayar (Euphorbiaceae). Int J PharmTech Res 2011;3:2169-74.

4. Kaur K, Gupta AK, Ahmad S, Alam P. Pharmacognostic studies on bark of Murraya koenigii Spreng. Int J Res Pharma Biomed Sci 2011;2:1670-77.

5. Kunle OF, Egharevba HM, Ahmadu PO. Standardization of herbal medicines: A review. Int $\mathrm{J}$ Biodivers Conserv 2012;4:101-12.

6. Kadam PV, Yadav KN, Narappanawar NS, Shivatare RS, Bhusnar HU, Patil MJ. Development of quality standards of Terminalia catappa Leaves. Pharmacogn J 2011;3:19-24.

7. Ghosh P, Chowdhury HR. Pharmacognostic, phytochemical and antioxidant studies of Adenanthera pavonina $\mathrm{L}$. Int $\mathrm{J}$ Pharmacogn Phytochem Res 2015;7:30-37.

8. Tabasum S, Khare S, Jain K. Spectrophotometric quantification of total phenolic, flavonoid and alkaloid contents of Abrus precatorius L. seeds. Asian J Pharma Clin Res 2016;9:1-4.
9. Tabasum S, Khare S, Jain K. Acute oral toxicity of hydromethanolic extract of Abrus precatorius L. seeds in Wistar rats. Int J Pharm Sci Rev Res 2016;38:155-58.

10. Shourie A, Kalra K. Analysis of phytochemical constituents and pharmacological properties of Abrus precatorius L. Int J Pharma Bio Sci 2013;4:91-101.

11. Boericke W, Oscar BE. Homeopathic Materia Medica. Vol. 2. USA: Kessinger Publishing; 2004.

12. Monago CC, Alumanah EO. Antidiabetic effect of chloroformmethanol extracts of Abrus precatorius Linn. seed in Alloxan diabetic rabbit. J Appl Sci Environ Manage 2005;9:85-88.

13. Bhutia SK, Mallick SK, Maiti S, Maiti TK. Antitumor and proapoptotic effect of Abrus agglutinin derived peptide in Dalton's lymphoma tumor model. Chem Biol Interact 2008;174:11-18.

14. Asolkar LV, Kakkar KK, Chakre OJ. Second Supplement to Glossary of Indian Medicinal plants with Active principles, Part-I (A-K), (1965-81). New Delhi: National Institute of Science Communication, CSIR; 1992.

15. Adelowotan O, Aibinu I, Adenipekun E, Odugbemi T. The invitro antimicrobial activity of Abrus precatorius L. Fabaceae extract on some clinical pathogens. Niger Postgrad Med J 2008;15:32-7.

16. Ligha A, Jaja B, Numbere NF. Protective effect of Abrus precatorius $\mathrm{L}$. seed extract following alcohol induced renal damage. Eur J Sci Res 2009;25:428-36.

17. Garaniya N, Bapodra A. Ethno botanical and Phytophrmacological potential of Abrus precatorius L.: A review. Asian Pac J Trop Biomed 2014;4:27-34.

18. Nath D, Sethi N. Commonly used Indian Abortifacient plants with special reference to their teratologic effects in rats. J Ethnopharmacol 1992;36:147-54.

19. Anonymous. Wealth of India- A Dictionary of Indian Raw Materials and Industrial Products. Vol 1. New Delhi: National Institute of Science Communication, CSIR; 1985.

20. Chopra RN, Chopra IC, Handa KL, Kapur LD. Indigenous drugs of India. 2nd ed. Calcutta: U. N. Dhur and Sons Pvt. Ltd.; 1958.

21. Duke AK. Handbook of Medicinal Herbs. $2^{\text {nd }}$ ed. Boca Raton (Florida): CRC Press; 2001.

22. Singh S, Pandey P, Kumar S. Traditional knowledge on the medicinal plants of Ayurveda. Lucknow (India): Central Institute of Medicinal and Aromatic Plants; 2000.

23. Rajaram N, Janardhanan KV. The chemical composition and nutritional potential of the trible pulse, Abrus precatorius L. Plant Food Hum Nutr 1992;42:285-90.

24. Pandey VN. Leaf protein content and yield of some Indian legumes. Plant Food Hum Nutr 1994;46:313-22.

25. Kokate CK. Practical Pharmacognosy. 4th ed. Delhi: Vallabh Prakashan; 1994.

26. Brain KR, Turner TD. The Practical Evaluation of Phytopharmaceuticals. 1st ed. Bristol: Wright Scienechnica; 1975.

27. Govt of India. The Ayurvedic Pharmacopoeia of IndiaPart I. 1st ed. New Delhi: Department of Ayurveda, YogaNaturopathy, Unani, Siddha and Homeopathy (AYUSH), Ministry of Health and Family Welfare; 2008.

28. Stahl E. Thin Layer Chromatography-A Laboratory Handbook. 2nd ed. Berlin: Springer Verlag; 2005.

29. Chanda S. Importance of pharmacognostic study of medicinal plants: An overview. J Pharmacogn Phytochem 2014;2:69-73. 